\title{
MENINGKATKAN PERAN IBU RUMAH TANGGA DALAM PENGELOLAAN KEUANGAN
}

\section{IMPROVING THE ROLE OF HOUSEHOLDS IN FINANCIAL MANAGEMENT}

\author{
${ }^{1)}$ Agus Supandi Soegoto, ${ }^{2}$ Diana N. Lintong, \\ ${ }^{3)}$ Syermi S.E. Mintalangi, ${ }^{4}$ Deasy Soeikromo \\ ${ }^{1)}$ Program Studi Manajemen, Fakultas Ekonomi dan Bisnis, \\ ${ }^{2,3)}$ Program Studi Akuntansi, Fakultas Ekonomi dan Bisnis, \\ ${ }^{4}$ Pogram Studi Ilmu Hukum, Fakultas Hukum \\ Universitas Sam Ratulangi \\ Jl. Kampus Bahu UNSRAT, Sario Manado 95115 \\ Email: supandi@unsrat.ac.id
}

\begin{abstract}
ABSTRAK
Komponen utama dari masyarakat adalah keluarga yaitu tempat yang nyaman bagi para anggota untuk hidup, beraktifitas dan mencapai kesejahteraan. Peran seorang ibu dalam keluarga sangat penting, terutama untuk mengelola keuangan. Masalah utama yang sering terjadi dalam tata kelola keuangan keluarga, yaitu tidak ada perencanaan kas, penghasilan selalu habis untuk dibelanjakan, minimnya pengetahuan dan keterampilan manajemen keuangan keluarga. Kegiatan ini bertujuan untuk: 1) meningkatkan pengetahuan dan keterampilan manajemen keuangan dan pengelolaan kas, dan 2) meningkatkan peran ibu rumah tangga dalam pengelolaan keuangan. Pelaksanaan pengabdian dilakukan di kelurahan Lewet kecamatan Amurang, kabupaten Minahasa Selatan. Metode yang digunakan berupa Pendidikan dan Pelatihan Masyarakat, dengan cara : 1) penyuluhan untuk meningkatkan pemahaman serta kesadaran para peserta, 2) demonstrasi untuk menyusun laporan keuangan sederhan, 3) pelatihan untuk membuat perencanaan kas dan mengelola keuangan. Hasil kegiatan menunjukkan bahwa terjadi peningkatan kemampuan para peserta dalam manajemen keuangan keluarga, peningkatan kerampilan dalam perencanaan dan pengelolaan kas, dan peningkatan peran ibu rumah tangga dalam mengendalikan biaya-biaya harian rumah tangga.
\end{abstract}

Kata kunci: Peran; Perencanaan Kas; Pengelolaan Kas

\begin{abstract}
The main component of society is the family, a comfortable place for members to live, work, and prosper. The role of a mother in the family is crucial, especially to manage finances. The main problems that often occur in family financial management, namely no cash planning, income are always spent to spend, lack of knowledge and skills in family financial management. This activity aims to: 1) increase the knowledge and skills of financial management and cash management, and 2) enhance the role of housewives in financial management. The service was carried out in Lewet village, Amurang sub-district, South Minahasa regency. The method used in the form of Community Education and Training, by 1) counseling to increase the understanding and awareness of the participants, 2) demonstrations to prepare simple financial reports, 3) training to do cash planning, and manage finances. The results of the activity showed that there was an increase in the ability of the participants in family financial management, increased skills in cash planning and management, and an increase in the role of housewives in controlling daily household costs.
\end{abstract}

Keywords: Role; Cash Planning; Cash Management

Submitted :22 September 2019 Revision : 1 November 2019 Accepted : 20 Februari 2020 


\section{PENDAHULUAN}

Pemberdayaan Masyarakat adalah upaya mengembangkan kemandirian dan kesejah-teraan masyarakat dengan meningkatkan pengetahuan, sikap, keterampilan, perilaku, kemampuan, kesadaran, serta memanfaatkan sumber daya melalui serangkaian kebijakan, program, kegiatan dan pendampingan yang sesuai dengan esensi masalah dan prioritas kebutuhan masyarakat. Masyarakat memiliki komponen utama yaitu keluarga. Keluarga memiliki fungsi perlindungan berkaitan dengan dimensi sosial kemasyarakatan, dimana keluarga menjadi satu tempat yang nyaman bagi anggotanya (Astuti \& Winarni, 2018). Dalam tata kelola keuangan keluarga, permasalahan utama yang sering dihadapi adalah: 1) kurangnya pengetahuan dan keterampilan manajemen keuangan ibu rumah tangga, dan 2) dibutuhkan tindakan nyata untuk membantu ibu rumah tangga dalam upaya meningkatkan kemampuan pengelolaan keuangan keluarga secara efektif dan efisien.

Solusi untuk mengatasinya adalah memberikan pelatihan manajemen bagi ibu rumah tangga untuk memberikan pengetahuan dan keterampilan manajemen melalui kegiatan perencanaan, pengorganisasian, pengarahan dan pengawasan terhadap aktivitas produksi, keuangan/akuntansi, pemasaran dan sumber daya manusia. Setelah mengikuti penyuluhan dan pelatihan ini diharapkan ibu rumah tangga di kelurahan Lewet akan memiliki pengetahuan manajemen dan terampil dalam membuat perencanaan, pengelolaan keuangan/ akuntansi secara sederhana, dan mampu untuk membuat perencanaan anggraan dalam mengelola keuangan rumah tangganya.

Penerapan program ini ditempuh dengan cara pelatihan dengan metode studi kasus, latihan-latihan memecahkan masalah tentang Manajemen Modal Usaha dan Pengelolaan Kas. Hasil program PKM akan disebarluaskan dalam bentuk artikel pada jurnal. Program PKM yang dilaksanakan ini diharapkan akan dapat menghasilkan luaran berupa: Peningkatan pengetahuan dan keterampilan manajemen keuangan keluarga dan peningkatan keterampilan dalam mangelola kas baik untuk kegiatan harian, mingguan dan bulanan,serta peningkatan pemahaman dan keterampilan dalam pengelolaan Kas Usaha.

Program dilaksanakan melalui Pengem-bangan pelatihan pada kegiatan Pengabdian Masyarakat, khususnya fokus pada bidang Manajemen Modal Usaha dan Pengelolaan Kas yang berkaitan dengan Pengelolaan Keuangan bagi ibu rumah tangga dilaksanakan di Kelurahan Lewet Kecamatan Amurang Kabupaten Minahasa Selatan bagi ibu rumah tangga dilaksanakan di Kelurahan Lewet Kecamatan Amurang Kabupaten Minahasa Selatan.

Pelatihan perencanaan kas dan manajemen keuangan keluarga ini dipilih karena memiliki kelebihan yaitu berkaitan dengan aktifitas sehari-hari dari para ibu rumah tangga, juga mudah di implementasikan, murah dan ringan serta bersifat kekinian sehingga akan menarik perhatian para peserta yaitu ibu-ibu rumah tangga. Kolaborasi antara pelatihan dengan strategi kewirausahaan melalui usaha bisnis, dapat mendatangkan keuntungan sekaligus dapat dijadikan sebagai sarana penerapan hasil pelatihan secara langsung (Herdiana \& Kurniawan, 2017). Sementara program lainnya hanya memfokuskan pada program yang sejenis seperti program pelatihan saja (Irawan, 2016) atau program kewirausahaan saja (Andriani, Novianti, \& Fatati. 2014). Hal lain yang ditambahkan dalam kegiatan pengabdian masyarakat ini yaitu selain metode penlatihan yang dilakukan disertai adanya diskusi secara langsung dengan para peserta juga dilakukan penerapan perencanaan kas dan manajemen keuangan keluarga (dengan metode simulasi), sehingga para peserta merasa bahwa mereka benar-benar mengelola penghasilan yang fluktuatif yang diterima dari suami mereka untuk mereka kelola.

Tugas seorang ibu Rumah Tangga saat ini penuh tantangan, banyak hal yang perlu dipertimbangkan dan dipersiapkan, termasuk dalam mengatur keuangan rumah tangga. Mengatur keuangan rumah tangga perlu perencanaan dan pengelolaan yang baik. Anggaran rumah tanggaa kadangkala menghadapi kebutuhan tambahan yang mengharuskan untuk mengeluarkan uang melebihi anggaran rutin yang berdampak terhadap belanja rutin atau pemenuhan pada 
keperluan yang akan datang, akibat lainnya keluarga tidak memiliki tabungan. Salah satu permasalahannya karena manajemen keuangan yang kurang tepat. Cara mengelola gaji dan penerimaan lainnya, sangat berpengaruh terhadap ketentraman dan kesejahteraan keluarga termasuk dalam pengelolaan seperti: dana darurat, biaya kuliah, dana pensiun, membeli mobil, dan sebagainya. Tidak dikelolanya dengan baik penghasilan, dapat berakibat keluarga tersebut kehabisan uang pada pertengahan bulan, sehingga memunculkan risiko meminjam untuk menutupi defisit,meski dengan bunga yang tinggi. Fenomena ini muncul karena banyak keluarga termasuk ibu-ibu rumah tangga yang belum memahami cara mengelola keuangan dengan baik dan benar. Berdasarkan latar belakang dan permasalahan tersebut, kegiatan pengabdian ini dilakukan dengan tujuan (a) meningkatan pengetahuan dan keterampilan manajemen keuangan keluarga; (b) meningkatan pengetahuan dan keterampilan perencanaan dan pengelolaan kas keluarga, dan (c) meningkatkan partisipasi dan peran aktif ibu-ibu rumah tangga dalam manajemen keuangan keluarga.

\section{METODE}

Pelaksanaan pengabdian dilakukan di kelurahan Lewet kecamatan Amurang, kabupaten Minahasa Selatan, pada tanggal 10 Agustus 2019 yang dimulai pukul 09.00 dan berakhir pukul 16.00 Wita. Metode yang digunakan berupa Pendidikan Masyarakat disertai Pelatihan, dengan cara penyuluhan untuk meningkatkan pemahaman serta kesadaran para peserta, juga dilakukan demonstrasi untuk penyusunan laporan keuangan sederhana diikuti latihan bagi masing-masing peserta untuk membuat perencanaan kas dan mengelola keuangan. Mitra pelatihan yaitu ibu-ibu rumah tangga di kelurahan Lewet sebanyak 21 peserta yang dibagi menjadi 3 (tiga) kelompok yaitu: Kelompok Aktiva (1, 2 \& 3). Pembagian Mitra menjadi 3 kelompok, bertujuan untuk menumbuhkan kekompakan, terjadinya interaksi, serta menumbuhkan rasa percaya diri para peserta. Pendidikan dan pelatihan keuangan ini dilakukan dengan cara penyuluhan, disertai demonstrasi dan latihan menyusun laporan keuangan sederhana dengan melakukan praktik langsung/Learning by doing (Rosita, Kusasih \& Istiyanto, 2017). serta diskusi terhadap masalah keuangan keluarga yang dihadapi para peserta. Materi yang disam-paikan yaitu: a) Manajemen keuangan sederhana; b) Rencana Anggaran kas keluarga, dan c) Peran ibu rumah tangga dalam mangelola keuangan keluarga.

Kerja sama antara mitra dengan tim pengabdian juga dilakukan untuk menciptakan kegiatan yang berkelanjutan. Bentuk kerja sama yang dilakukan pada tahap awal berupa perancangan program materi penyuluhan dan pelatihan yang akan disampaikan kepada para peserta. Konsep pengabdian masyarakat melalui peningkatan kapasitas atau kemampuan perencanaan kas keuangan keluarga maupun manajemen keuangan keluarga ini mengacu kepada prinsip pemberdayaan masyarakat menurut Soetomo (2012), dimana fokus ditujukan pada komunitas sebagai sesuatu yang utuh/bulat, berorientasi pada kebutuhan dan permasalahan, dengan mengutamakan prakarsa, partisipasi, dan swadaya masyarakat. Dari segi proses, Mardikanto \& Subianto, (2012) menyatakan proses pemberdayaan masyarakat merupakan upaya yang sengaja dilakukan untuk memfalisitasi masyarakat lokal dalam merencanakan, memutuskan, dan mengelola sumber daya lokal yang dimiliki melalui collective action dan networking sehingga mereka memiliki kemampuan dan kemandirian secara ekonomi, ekologi, dan sosial. Usman (2004) mengemukakan beberapa strategi yang dapat menjadi pertimbangan untuk dipilih dan diterapkan dalam pemberdayaan masyarakat, yaitu menciptakan iklim, memperkuat daya, dan melindungi.

Berdasarkan konsep tersebut maka pengabdian masyarakat yang dilakukan menggunakan pendekatan: 1) Program dilakukan secara terarah (fokus), yang ditujukan langsung kepada yang membutuhkan dengan program yang dirancang untuk mengatasi masalahnya sesuai kebutuhan, 2) kedua Program secara langsung mengikutsertakan dan dapat dilaksanakan masyarakat yang menjadi sasaran. Dengan cara mengikutsertakan masyarakat khususnya ibuibu rumah tangga dalam pelatihan perencanaan 
kas dan manajemen keuangan keluarga. Penyampaian materi penyuluhan diberikan sepenuhnya kepada tim pengabdian, sedangkan mitra menyiapkan ruang pertemuan dan undangan untuk disebarkan kepada para peserta. Pada tahap selanjutnya, mitra dan peserta penyuluhan melakukan pembinaan lebih lanjut kepada masyarakat umum dan akan menjembatani semua kegiatan pengembangan kegiatan manajemen keuangan keluarga.

Waktu yang direncanakan sejak persiapan, koordinasi dengan Mitra ibu Rumah Tangga dan administrasi sampai pelaksanaaan kegiatan evaluasi dan pelaporan hasil kegiatan kurang lebih selama sembilan bulan, yaitu sejak tanggal 1 Februari sampai 30 Oktober 2019. Bulan pertama dan kedua digunakan untuk kegiatan persiapan dan survey potensi dan objek pengabdian. Bulan ketiga dan keempat digunakan untuk perancangan materi pelatihan dan koordinasi Tim. Bulan kelima dan keenam digunakan untuk pelaksanaan. Bulan ketujuh dan kedelapan digunakan untuk evaluasi hasil dan keberlanjutan kegiatan. Bulan kesembilan dan kesepuluh digunakan untuk menyelesaikan laporan akhir kegiatan serta presentasi hasil.

\section{HASIL DAN PEMBAHASAN}

\section{Potensi Penerapan Program Pada Kelurahan Lewet}

Kelurahan Lewet merupakan sebuah kelurahan di wilayah kecamatan Amurang, kabupaten Minahasa Selatan, yang memiliki kontribusi besar dalam pertumbuhan penduduk maupun ekonomi di Kabupaten Minahasa Selatan (Pattymahu, 2018). Data Badan Pusat Statistik (BPS) Kabupaten Minahasa Selatan (2019), Kecamatan Amurang pada Tahun 2017 memiliki penduduk sebanyak 18.447.000 jiwa (terbanyak), disusul kecamatan Tenga (17.944.000 orang), dan Tumpaan (17.061.000 orang). Kelurahan Lewet terletak di tengah kota Amurang yang mobilisasi masyarakatnya sangat tinggi, terutama dalam bekerja dan aktivitas ekonomi untuk memenuhi kebutuhan keluarga.

Hasil pengamatan awal, diperoleh gambaran bahwa masyarakat kelurahan Lewet, mobiltasnya tinggi, suami berperan sebagai kepala rumah tangga, sedangkan ibu rumahtangga rata-rata berperan mengelola rumah, membesarkan anak, termasuk dipercaya mengelola penghasilan bulanan atau harian yang diterima dari para suami yang bekerja.

Data lainnya menunjukkan bahwa ibuibu rumah tangga di kelurahan Lewet ada yang bekerja sebagai Pegawai negeri sipil (PNS), karyawan, wirausaha dan lainnya berprofesi sebagai ibu rumah tangga (tidak bekerja). Hasil wawancara pendahuluan yang dilakukan dapat disimpulkan bahwa ibu-ibu rumah tangga di kelurahan Lewet 90 (mayoritas) tidak tahu mengelola keuangan dan biasanya langsung menghabiskan uang yang diberikan suami/didapat tanpa disisihkan. Sebanyak $10 \square$ ibu rumah tangga tahu, dan agak paham dalam mengelola keuangan, termasuk menyisihkan uang untuk ditabung. Oleh karena itu, apabila ibu-ibu rumah tangga ini diberikan pelatihan dan dapat memahami dengan baik manajemen keuangan keluarga, akan sangat bermanfaat dalam: a) meningkatkan pengetahuan pengelolaan keuangan keluarga; b) meningkatkan keterampilan dalam perenca-naan kas; dan (c) meningkatkan pendapatan ekonomi keluarga, melalui pemahaman pengelolaan kas dan investasi dari uang yang diterima.

\section{Peran Ibu Rumah Tangga dalam Mengelola Keuangan Keluarga}

Pada awal kegiatan diperoleh gambaran bahwa pemahaman peserta pelatihan (Kelompok Aktiva 1, $2 \& 3$ ) beragam, hal ini disebabkan dalam aktifitas anggota kelompok tersebut sehari-hari khususnya dalam pengelolaan keuangan keluarga hanya berdasarkan intusi/ pengetahuan sendiri (25\%), diskusi dan persetujuan suami/keluarga (65\%) dan sisanya bertanya kepada teman/orang yang dapat dipercaya (10\%). Dalam kegiatan seharihari khususnya penggunaan uang belanja yang diterima dari suami/penghasilan tambahan, ibu-ibu rumah tangga ini ada yang langsung membelanjakan $(80 \%)$ uang yang diterima dengan alasan untuk memenuhi kebutuhan sehari-hari dan sisanya (20\%) ibu-ibu tersebut menyisihkan sebagian uang yang diterima untuk berjaga-jaga bila ada keperluan yang mendesak. 
Kerja sama antara Mitra (Lurah dan Perangkat desa) dengan Tim Pengabdian sebelumnya telah dilakukan untuk merancang dan melaksanakan kegiatan yang sesuai kebutuhan masyarakat Lewet. Bentuk kerja sama yang dilakukan pada tahap awal berupa perancangan program materi penyuluhan dan pelatihan yang akan disampaikan kepada para peserta. Tim pengabdian melakukan penyusunan materi sesuai kesepakatan awal.

Dalam pelaksanaannya penyampaian materi pendidikan diberikan sepenuhnya kepada Tim PKM, sedangkan mitra bertugas menyiapkan tempat pelatihan dan undangan untuk disebarkan kepada para peserta utama yaitu ibu-ibu rumah tangga di kelurahan Lewet. Pelaksanaan kegiatan pendidikan dilakukan diruang Pertemuan dirumah Ketua penggerak PKK di Kelurahan Lewet Kecamatan Amurang Kabupaten Minahasa Selatan.

Kegiatan ini mendapat respon positif dan ketertarikan dari ibu-ibu rumah tangga dan pengurus PKK di Kelurahan Lewet Kecamatan Amurang Kabupaten Minahasa Selatan. Untuk melihat lebih jauh partispasi yang diberikan masyarakat khususnya ibu-ibu rumah tangga dalam kegiatan penyuluhan dan pelatihan maka oleh Tim dilakukan evaluasi awal kepada para peserta pendidikan dan pelatihan serta masyarakat umum. Peserta penyuluhan dan pelatihan diwawancarai dengan menggunakan kuesioner sebelum dan setelah penyuluhan selesai, sedangkan masyarakat umum diwawancarai pada hari berikutnya. Hasil tanggapan peserta pendidikan dan pelatihan dan masyarakat umum, baik yang mengikuti pendidikan maupun yang tidak terkait dengan keinginan untuk berpartisipasi dalam proses kegiatan pengabdian masyarakat ini, dapat dilihat pada Tabel 1 berikut ini.
Tabel 1. Animo Masyarakat Berpartisipasi pada kegiatan PKM Manajemen Keuangan

Keluarga.

\begin{tabular}{|c|c|c|c|c|c|c|c|}
\hline \multirow{3}{*}{$\begin{array}{c}\text { No } \\
\text {. }\end{array}$} & \multirow{3}{*}{$\begin{array}{c}\text { Kategori } \\
\text { Masyarakat }\end{array}$} & \multicolumn{4}{|c|}{$\begin{array}{c}\text { Akan Berpartisipasi dan } \\
\text { Berperan Aktif }\end{array}$} & \multirow{2}{*}{\multicolumn{2}{|c|}{ Jumlah }} \\
\hline & & \multicolumn{2}{|c|}{$\begin{array}{l}\text { Partisipasi } \\
\text { Penuh }\end{array}$} & \multicolumn{2}{|c|}{$\begin{array}{c}\text { Partisipasi } \\
\text { Tidak Penuh }\end{array}$} & & \\
\hline & & $\begin{array}{l}\text { Fre- } \\
\text { kuens } \\
\mathrm{i}\end{array}$ & $\begin{array}{c}\text { Perse } \\
\mathrm{n} \\
(\%)\end{array}$ & $\begin{array}{l}\text { Fre- } \\
\text { kuens } \\
\mathrm{i}\end{array}$ & $\begin{array}{l}\text { Perse } \\
\mathrm{n}(\%)\end{array}$ & $\begin{array}{c}\text { Fre- } \\
\text { kuens } \\
\text { i }\end{array}$ & $\begin{array}{c}\text { Persen } \\
(\%)\end{array}$ \\
\hline 1. & $\begin{array}{l}\text { Peserta } \\
\text { Pelatihan }\end{array}$ & 21 & 70,00 & 0 & 0,0 & 21 & 70,00 \\
\hline 2. & $\begin{array}{l}\text { Peserta Non } \\
\text { Pelatihan }\end{array}$ & 9 & 30,00 & 2 & $\begin{array}{c}100,0 \\
0\end{array}$ & 9 & 30,00 \\
\hline & Jumlah & 30 & $\begin{array}{c}100,0 \\
0\end{array}$ & 2 & $\begin{array}{c}100,0 \\
0\end{array}$ & 30 & 100,0 \\
\hline
\end{tabular}

Sumber : Hasil Pengolahan Data PKM, 2019.

Tabel 1 menunjukkan bahwa masyarakat di Kelurahan Lewet Kecamatan Amurang Kabupaten Minahasa Selatan menanggapi secara positif dan antusias terhadap program PKM yang ditawarkan oleh Tim PKM Fakultas Ekonomi dan Bisnis (FEB) Unsrat. Meskipun terdapat perbedaan terhadap jawaban responden yang menjadi target yaitu pada masyarakat di kelurahan Lewet namun perbedaan tersebut tidaklah signifikan nilainya.

Data pada Tabel 1 juga menunjukkan adanya antusiasme masyarakat untuk mengikuti kegiatan PKM. Masyarakat/ibu-ibu rumah tangga yang mengikuti penyuluhan dan pelatihan sebanyak 21 orang $(70 \square)$, sedangkan yang tidak mengikuti namun ikut berpartisipasi (ikut memberi masukan) terhadap kegiatan sebanyak 9 orang (30 $\square)$. Semua masyarakat yang mengikuti kegiatan pelatihan (peserta pelatihan) sebanyak (100,0\%). Untuk masyarakat yang tidak berpartisipasi penuh dalam kegiatan pengabdian masyarakat sebanyak 2 orang, dengan alasan adanya tugastugas yang harus segera diselesaikan dan ingin memperoleh informasi secara langsung dari para ibu-ibu/rekannya yang sudah mengikuti pendidikan dan pelatihan ini. Terhadap hasil kegiatan atau penerapan program yang dilakukan dapat dilihat pada Tabel 2 berikut ini: 
Tabel 2. Tanggapan Peserta Pelatihan pada Manajemen Kas Keluarga

\begin{tabular}{|l|l|c|c|c|}
\hline No. & $\begin{array}{l}\text { Jenis Rencana } \\
\text { Penerapan }\end{array}$ & Jumlah & $\begin{array}{c}\text { Fre- } \\
\text { kuensi }\end{array}$ & $\begin{array}{c}\text { Persen } \\
(\%)\end{array}$ \\
\hline 1. & $\begin{array}{l}\text { Perencanaan } \\
\text { Kas }\end{array}$ & 21 & 21 & 100 \\
\hline 2. & Kas Harian & 21 & 21 & 100 \\
\hline 3. & Kas Mingguan & 21 & 19 & 90 \\
\hline 4. & Kas Bulanan & 21 & 19 & 90 \\
\hline 5. & $\begin{array}{l}\text { Investasi } \\
\text { (Tabungan, dll) }\end{array}$ & 21 & 12 & 57 \\
\hline
\end{tabular}

Sumber: Hasil Pengolahan Data PKM, 2019

Tabel 2 menunjukkan bahwa para peserta (Kelompok Aktiva 1, 2 \& 3) Pelatihan Manajemen Kas keluarga mampu menyerap dengan baik materi hasil pelatihan yang disampaikan dan mampu untuk mengaplikasikan materi Perencanaan Kas dalam keuangan keluarga. Jumlah keluarga yaitu ibuibu rumah tangga peserta pelatihan yang telah mampu merencanakan dan mengaplikasikan Perencanaan Kas secara baik 100\%.

Dalam Perencanaan Kas Harian sebanyak $100 \%$ anggota Kelompok Aktiva 1, 2 \& 3, telah mampu menerapkan dengan baik arus kas masuk (penerimaan) dan arus kas keluar (biaya-biaya) dalam aktifitas keuangan keluarga, baik dari hasil penerimaan tetap maupun tidak tetap yang dimiliki oleh keluarga tersebut. Perencanaan dan penerapan Kas Mingguan sebanyak 90\% telah mampu menerapkan dengan baik arus kas masuk (penerimaan) dan arus kas keluar (biaya-biaya) dalam aktifitas keuangan Keluarga secara mingguan baik hasil penerimaan tetap maupun tidak tetap yang diperoleh dari keluarga tersebut. Terhadap Perencanaan Kas Bulanan memiliki kesamaan dengan Kas Mingguan dalam manajemen Kas baik arus kas masuk (penerimaan) dan arus kas keluar (biaya-biaya) dalam aktifitas keuangan keluarga. Sedangkan untuk rencana investasi dari penyisihan dana (30\% dari nilai pendapatan) baik dari hasil tetap maupun tidak tetap yang diterima masing-masing ibu rumah tangga, sebanyak $57 \%$ yang menyatakan sanggup untuk melakukan investasi pada bank, sebagai bentuk investasi tetap, sedangkan sisanya $43 \%$ memiliki minat untukmelakukan penyisihan penghasilan yang diterima,akan tetapimeerasa bahwa anggaran untuk kebutuhan rumah tangga belum cukup untuk itu.

Hasil pelaksanaan kegiatan pengabdian ini, menunjukkan bahwa masyarakat di kelurahan Lewet kecamatan Amurang, menanggapi secara positif dan antusias untuk mengikuti kegiatan pengabdian masyarakat yang ditawarkan Tim PKM melalui Mitra (lihat Tabel 1). Data pada Tabel 1 menunjukkan adanya antusiasme yang tinggi dari masyarakat untuk mengikuti kegiatan PKM, dimana dari 30 ibu rumah tangga yang diminta pendapatnya sebanyak 21 orang (70\%) menyatakan akan berpartisipasi dan berperan aktif dalam kegiatan PKM, sementara sisanya sebanyak 9 orang $(30 \%)$ menyatakan tidak bisa mengikuti kegiatan namun akan ikut berpartisipasi (memberi masukan) terhadap kegiatan bila diperlukan, dengan alasan sebelumnya sudah memiliki agenda kegiatan lain yang penting untuk segera dilaksanakan, pada saat kegiatan pelatihan berlangsung. Dari 9 orang yang menyatakan tidak bisa mengikuti kegiatan, ada 2 orang yang datang dan berpartisipasi pada sesi pertengahan sampai akhir acara PKM.

Hasil pre test menunjukkan bahwa ibuibu rumah tangga peserta pelatihan 95\% (mayoritas) tidak tahu mengelola keuangan dan biasa langsung menghabiskan uang yang mereka terima tanpa disisihkan (karena kebiasaan), sedangkan sisanya 5\% menyatakan paham dalam mengelola keuangan, termasuk dapat menyisihkan uang untuk mereka tabung, namun kegiatan ini masih bersifat sewaktu-waktu (temporer) dan belum menjadi kebiasaan rutin.

Hasil kegiatan (evaluasi post test), 90\% peserta kegiatan menyatakan mereka memahami hasil pendidikan dan pelatihan dengan baik, $10 \%$ menyatakan mereka kurang paham, dan ingin ikut pelatihan bila akan diadakan kembali. Alasan peserta merasa kurang paham, karena merasa pelatihan ini merupakan suatu hal yang baru, dan mereka belum terbiasa dengan kegiatan pencatatan uang masuk dan uang keluar, yang kemudian direncanakan secara rutin. 
Hasil kegiatan yang berkaitan dengan perencanaan kas dan keuangan keluarga, dapat dilihat pada Tabel 2. Untuk rencana investasi dari penyisihan dana $(30 \%$ dari nilai pendapatan) keluarga tersebut $57 \%$ peserta pelatihan menyatakan tertarik dan sanggup untuk menyisihkan dan melakukan investasi pada bank baik dalam bentuk tabungan maupun untuk didepositokan agar return (imbal hasil) yang diterima dapat lebih tinggi. Untuk sisanya sebanyak $43 \%$ memiliki minat untuk berinvestasi dengan menyisihkan penghasilan yang diterima, namun mereka merasa penghasilan yang diterima impas dengan biaya-biaya untuk kebutuhan rumah tangga.

Hasil kegiatan ini memberikan gambaran secara umum bahwa peran serta aktif masyarakat yang sangat baik dalam mengikuti kegiatan pendidikan dan pelatihan,yang telah dirancang Tim PKM telah mendorong mereka untuk menyampaikan informasi kepada warga lainnya, baik secara langsung maupun tidak langsung. Peran serta aktif masyarakat juga tampak dari keinginan mereka untuk mencoba mengem-bangkan usaha sendiri (usaha mikro), dari pemahaman pengelolaan keuangan keluarga untuk tambahan penghasilan keluarga merupakan sebuah nilai tambah yang positif. Hasil PKM ini sejalan dengan kegiatan PKM yang dilakukan oleh Rosita, Kusasih \& Istiyanto (2017) yang menyatakan pembuatan anggaran bertujuan agar mitra memiliki rencana untuk proses produksi, sehingga kegiatan usaha mitra lebih terarah dan dapat membandingkan dengan realisasinya, pendapat yang serupa juga disampaikan Octaviani, Narti \& Nurwita, (2019) bahwa agar usaha mitra dapat berkelanjutan, maka dilakukan pelatihan dan pendampingan dibidang manajemen untuk administrasi, keuangan dan pemasaran.

Tim PKM menyarankan pada masyarakat di kelurahan Lewet untuk memperbanyak kelompok-kelompok kerja ibu-ibu rumah tangga di masyarakat, sehingga dapat mempercepat penyebaran informasi dan meningkatkan keterampilan keuangan bagi para anggota kelompoknya, sehingga akan dapat mempercepat peningkatan kemampuan keuangan/ekonomi keluarga di kelurahan Lewet dan sekitarnya.

Kegiatan ini mendapatkan masukan berupa usulan warga dan ibu-ibu rumah tangga peserta pelatihan, agar kegiatan PKM dapat dilakukan kembali, dengan tujuan agar dapat lebih meningkatkan kemampuan keuangan rumah tangga di kelurahan Lewet dan sekitarnya melalui program kerjasama dibawah pembinaan perguruan tinggi dan pemerintah di kabupaten Minahasa Selatan.

\section{SIMPULAN}

Berdasarkan pembahasan hasil kegiatan pengabdian dapat disimpulkan bahwa: a) Ibu-ibu Rumah Tangga memiliki potensi yang besar untuk mengatur keuangan sehingga mereka memerlukan penyuluhan dan pelatihan perencanaan dan pengelolaan yang baik, termasuk menghadapi pengeluaran tidak terduga diluar anggaran rutin yang direncanakan; b) Apabila potensi ibu-ibu rumah tangga di Kelurahan Lewet dikembangkan maka masyarakatnya terutama ibu-ibu rumah tangga akan memiliki potensi yang tinggi untuk mendorong keluarga mereka memiliki struktur keuangan yang lebih baik, rumah tangga akan mampu mengelola keuangan dengan baik dan memiliki cadangan dana rumah tangga melalui tabungan dan deposito untuk berjaga-jaga; dan c) Setelah mengikuti pelatihan Ibu-ibu Rumah Tangga mampu memahami dan mengelola keuangan keluarga termasuk perencanaan Kas dalam mengendalikan biaya-biaya pada aktifitas rumah tangga yang dikelola, sehingga mereka bersedia untuk merekomendasikan diadakanya pelatihan lanjutan untuk meningkatkan.

\section{DAFTAR PUSTAKA}

Andriani, S. Novianti, dan Fatati. (2014). Usaha IbIKK Kambing Perah. Jurnal Pengabdian kepada Masyarakat Universitas Jambi. 29 (4), 1-10

Astuti , E.Z.L., \& Winarni, T., (2018). Mendorong Partisipasi Bina Keluarga Lansia (BKL) dalam Mewujudkan Tujuh Dimensi Lansia Tangguh di Desa Sumbersari, Moyudan, Sleman. Jurnal Pengabdian kepada Maysarkat, 3(2), 130-142.

Badan Pusat Statistik (BPS), Kabupaten Minahasa Selatan, (2019). Jumlah dan 
Agus Supandi Soegoto, Diana N. Lintong,

Syermi S.E. Mintalangi, Deasy Soeikromo

Meningkatkan Peran Ibu Rumah Tangga Dalam Pengelolaan Keuangan

Sebaran Penduduk Kabupaten

Minahasa Selatan. Amurang,

Minahasa Selatan. Diakses tanggal 12

September 2019.

Herdiana, B., \& Kurniawan, B., (2017). Program Iptek bagi Inovasi dan Kreatifitas Kampus IT Training \& Service Center (ITSC) UNIKOM. Jurnal Pengabdian Kepada Masyarakat, 3 (1) 18-25.

Irawan, B., (2016). Pelatihan dan Instalasi Jaringan LAN untuk Guru-Guru di Yayasan Perguruan Birrul Waalidain Semplak Bogor. Jurnal Pengabdian Masyarakat Abdimas, 2 (2), 1-5

Mardikanto, T., \& Subianto, P. (2012). Pemberdayaan Masyarakat dalam Perspektif Kebijakan Publik. Bandung: Alfabeta.

Octaviani, V., Narti, S. \& Nurwita, S., (2019). Peningkatan Sumberdaya Masyarakat
Desa Melalui Binan Pusat Kegiatan Belajar Masyarakat. Jurnal Pengabdian dan Pemberdayaan Masyarakat. 3(1), 9-17.

Pattymahu, Andrew. (2018). Camat Amurang Resmi Dijabat Rommy Rumagit. Tribun Manado. Diakses tanggal 12 September 2019.

Rosita, Kusasih, I.A.K.R., \& Istiyanto, B., (2017). Perbaikan Pengelolaan UMKM Guna Pengembangan Usaha Mikro. Jurnal Pengabdian dan Pemberdayaan Masyarakat, 1(1), 3037.

Soetomo, (2012). Pembangunan Masyarakat. Yogyakarta: Pustaka Pelajar.

Usman, S. (2004). Pembangunan dan Pemberdayaan Masyarakat. Yogyakarta: Pustaka Pelajar. 